ENSAYO

\title{
APUNTES PARA UNA TEORÍA DE LO QUIJOTESCO COMO VIRUS
}

\author{
Rodrigo Fresán
}

Clásicos vivos de la literatura hay muchos, pero pocos de ellos gozan del poder virósico y de contagio que tiene "Don Quijote de La Mancha". Novela a la vez fundante y clausuradora, entrada y salida de prácticamente todo lo que vino después, la gran obra de Cervantes - con un pie en los vetustos libros de caballería y otro en las playas del posmodernismo más experimental - no ha dejado de cabalgar durante cuatrocientos años. Pocas veces ha sido más lúcida e inteligente y sabia la historia de un hombre supuestamente loco. En las páginas que siguen, Rodrigo Fresán —agradecido y contaminado - recorre la ruta del cada vez más feliz caballero de la triste figura y examina los síntomas de una enfermedad para la que, afortunadamente, no hay ni jamás habrá cura alguna.

Rodrigo FresÁn. Escritor y periodista argentino, nació en Buenos Aires en 1963. Su primera obra, Historia argentina (1991), un libro de cuentos, fue elegida por la crítica como la revelación narrativa de 1991. Un segundo libro de relatos, Vidas de santos (1993), precedió a sus novelas Trabajos manuales (1994) y Esperanto (1995). En 1999 se trasladó a Barcelona, donde ha publicado las novelas Mantra (2001) y Jardines de Kensington (Premio Lateral de Narrativa Extranjera; 2003), además de versiones corregidas y aumentadas de algunos de sus libros anteriores.

Estudios Públicos, 100 (primavera 2005). 


\section{El comienzo}

$\mathrm{E}_{1}$ 1 comienzo es inequívocamente raro, único, novedoso y, paradójicamente, inolvidable teniendo en cuenta que de lo que aquí se habla es de una primera línea que sólo pide el consuelo del olvido.

En un lugar de La Mancha de cuyo nombre no quiero acordar$m e . .$. , leemos luego de algunas notas preliminares y versos introductorios; y nos decimos ¿qué pasa aquí?, ¿cómo es posible que una novela —animal que básica y genéricamente no es otra cosa que una forma sublimada de la memoria - arranque buscando el olvido? Y, a título muy personal, cómo olvidar la intriga y la inquietud que me causó durante mi infancia argentina y tan lejos de Castilla esa primera línea porque ... ¿cómo era posible que toda una novela transcurriera adentro de una mancha? ¿Una mancha de qué? ¿De salsa de tomate, de tierra, o de tinta? Luego alguien me explicó lo explicable; pero nadie puede explicar lo inexplicable y es esto, pienso, esta imposibilidad de cercarlos y de capturarlos, lo que distingue a los verdaderos clásicos.

Esta primera frase es, sí, uno de esos comienzos famosos y novelescos. Y como las primeras oraciones de Moby-Dick o En busca del tiempo perdido - otras dos novelas fundantes y revolucionarias - se ha convertido, como corresponde, en una feliz pesadilla para los traductores a otros idiomas.

Leo en la revista norteamericana The Believer un ensayo firmado por la traductora norteamericana Natasha Wimmer donde se refiere a la nueva traducción norteamericana de Don Quijote y donde se apunta la naturaleza líquida y cambiante de este comienzo y se recopilan sus varias mutaciones: "In a village of La Mancha the name of which I have no desire to recall"; "In a village in La Mancha, the name of which I cannot quite recall"; "In a certain village in La Mancha, which I do not wish to name"; "Somewhere in La Mancha, in a place whose name I do not care to remember"...

Cito aquí las variaciones inglesas porque el inglés es mi otro idioma. Nada me hace pensar que no ocurra lo mismo a la hora del alemán o el coreano o el esperanto o en cualquiera de las múltiples versiones y deformaciones surgidas casi instantáneamente del original y que incluyen desde una adaptación teatral de Molière a una para mí insoportable muestra de ese cine soviético donde todo, inevitablemente, simboliza la revolución del Hombre Nuevo y donde La Mancha, supongo, es una estepa siberiana sembrada con molinos falsos pero sentidos.

Aún así, las grandes obras, aunque parezcan dóciles, siempre se niegan a ser manipuladas — por más que se las trate con amor devocional- 
y no resulta fácil adaptarlas a otras costumbres y territorios. Así, paradójicamente, lo verdaderamente universal es aquello que nos hace conocer un nuevo mundo para apreciarlo como corresponde.

El caso del Quijote, sin embargo, es muy extraño y — tratándose de una apología/condena de la alucinación - ha sabido provocar comportamientos tan extremos como los de su protagonista en muchos de los que se acercan y se acercaron y, seguro, se acercarán a sus páginas.

Leo que Sigmund Freud quiso aprender español para poder diagnosticar mejor los síntomas de su patología.

Leo que Thomas Mann — creador del quijotesco Hans Castorpcelebró la particularidad de "este héroe que vive de su propia glorificación".

Leo una carta del siempre patológico y muy macho Ernest Hemingway donde asegura que no tendría problema alguno en pelear veinte rounds con Cervantes "en su propio Alcalá de Henares" y "hacerlo mierda" aunque "Mr. C. es muy astuto y después de esto se entrenaría fuerte y, seguramente, me ganaría a la hora de la revancha". Por las dudas, Hemingway aclara que no se siente capaz de ganarles a Mr. Shakespeare y a Mr. Anónimo.

Leo también que Jorge Luis Borges lo leyó por primera vez en inglés; y que Anthony Burgess lo descubrió en catalán; y que James Joyce en algún momento lo consideró como cimiento para su obra maestra pero que, finalmente, optó por La Odisea por considerarla una trama más épica y, por lo tanto, más digna de ser vulgarizada.

Y leo también que el eterno infant terrible Martin Amis no duda a la hora de clavarle una lanza al Quijote definiéndolo como magistral pero, también, "imposible de leer", "aburrido en un 75\%", "comparable a una de esas visitas del más insoportable y repetitivo y disgresivo de tus parientes" y "más una aglomeración que una antología de episodios". Amis precisa: "La cuestión de qué sucede después no tiene sentido en el Quijote porque aquí no hay después, sólo hay más". Amis justifica pero no disculpa todo esto llegando incluso a proponer incontables cortes y un hipotético pero, por favor, inmediato y radical editing a cargo de algún escritor latinoamericano (Amis sugiere a Carlos Fuentes) para así obtener un Quijote "más oscuro" de acuerdo con el clima del milenio. En cualquier caso, para Amis muchos de los defectos del libro de Cervantes se deben a que, después de todo, "es la sopa primigenia de la ficción" y — no todo está perdido- "una idea hermosa" cuyos principales méritos están en aquellos otros libros y épocas en las que influyó más que en los tiempos y el libro mismo donde habita y ocurre. 
No importa: a la hora de las transformaciones - ya sea "una aldea de La Mancha" o "alguna parte de La Mancha"; ya se trate de "no recordar del todo" o "no tener deseo de recordar"; más allá de toda distorsión de todo idioma o extranjerismo - está visto que Don Quijote de La Mancha mantendrá siempre intacta su formidable potencia tóxica, su alto poder de contagio, sus buenos modales de virus maleducado.

De ahí que, a la altura del prólogo, antes de que se nos informe que se quiere olvidar lo inolvidable, Cervantes nos dice a nosotros, "desocupados lectores", que "sin juramento me podrás creer que quisiera que este libro, como hijo del entendimiento, fuera el más hermoso, el más gallardo y más discreto que pudiera imaginarse" y después nos desea y se desea: "Dios te dé salud y a mí no olvide. Vale".

Y enseguida, a vuelta de página, Cervantes — no me parece casual que su padre haya sido cirujano - libera sobre la tierra y los lectores y las bibliotecas la novela más tóxica e incurable jamás escrita.

\section{Idea para una novela de ciencia-ficción}

Astronómicamente hablando, el Quijote es una suerte de Big Bang en reversa: una implosión de múltiples lecturas antiguas confluyendo en el punto de energía pura de un solo libro nuevo que, otra vez, explota: pienso, luego existo equivale - para el héroe de Cervantes - a leo, luego existo. Para el Quijote, las venerables novelas de caballería funcionan como puertas a otras dimensiones y - ya lo dije muchas veces, vuelvo a decirlo aquí - no me parece casual que el mecanismo de una puerta, en lo formal, sea exactamente igual al mecanismo de un libro.

Pasen y vean. Y lean.

$\mathrm{Y}$ ésta es mi idea para una novela de ciencia-ficción quijotesca. La tripulación de una nave espacial — seres absolutamente racionales y perfectos y realistas y exactos - acude en respuesta a la llamada de auxilio que proviene de un planeta que no figura en ninguna carta de navegación cósmica. Descienden sobre su superficie y llegan hasta los despojos de un extraño vehículo parecido a un primitivo molino de viento. Entran y lo único que encuentran en el interior es un ejemplar de algo que jamás vieron pero que es un libro. Demoran poco en decodificarlo y en leerlo. Cuando llegan a la última página ya están perdidos, ya están contaminados. De regreso en su planeta predican el nuevo evangelio y su civilización - luego de experimentar unos pocos años de desafuero creativo - se extingue como la llama de un fósforo. Antes de que esto ocurra, por primera vez en su fría y cerebral Historia, todos la pasan de puta madre. 


\section{El adjetivo}

Y si los editores fueran personas más honestas y menos preocupadas por economizar gastos, toda edición del Quijote debería venir con un sticker de advertencia, con una cautelosa pegatina — nada tan ominoso como una calavera sobre dos tibias, pero sí me parece apropiada la figura de ese hombre fulminado por un relámpago- que advirtiera ya desde la portada lo que ocurrirá cuando abramos el libro y respiremos el perfume vicioso que se desprende de sus páginas. O tal vez, mejor, una de esas ominosas advertencias escritas como la que se lee en el dintel del Infierno de Dante o en el umbral del sepulcro de Tut-Ank-Amon. Algo que nos previniera de la presencia de lo quijotesco.

$\mathrm{Y}$ es de lo quijotesco que tratan y pretenden tratar estas páginas. De esa variante de ese privilegio que desciende sobre ciertos nombres para convertirlos en adjetivo. Ya saben: kafkiano, felliniano, beatlesco, picassiano. Esa deformación del apellido - en este caso, atención, no del nombre del autor sino del nombre del personaje - que no significa otra cosa que mirada local ascendida a pupila global, a forma de ser y de ver y que, muy a menudo, equivale, me parece, a error de cálculo y de precisión. Porque se premia y se deforma y se adjetiviza el nombre cuando se ha conseguido un estilo y una estética particulares pensando - así lo sienten los de afueraque el portador del nombre y merecedor de la medalla del adjetivo ha descubierto algo nuevo y suyo cuando, en la mayoría de los casos, estos siempre indivisibles individuos no hacen otra cosa que escribir o filmar o musicalizar o pintar el mundo que ellos habitan y que, piensan, es común e igual al mundo de todos.

Así, el estilo - incluso el estilo de los genios- no sería otra cosa que el residuo que permanece luego del fracaso. A ver si me explico: uno acaba resignándose a lo que sabe hacer, va arrojando por la borda aquello que nunca hará bien $\mathrm{y}$, al final, los demás perciben como logros lo que en realidad es el sedimento aprovechable y, con suerte, cada vez más ennoblecido y depurado y perfecto de las frustraciones. Aquello que a un determinado artista le salió cuando en realidad quería hacer otra cosa y que, con el paso del tiempo, se va solidificando en lo único que éste puede hacer bien, en lo que hace como ninguno. A un lado, claro, queda toda esa obra fantasma. Todas esas posibilidades interrumpidas. Toda esa "quijotez" con el que sueña Quijano. Todo eso que se hubiera querido firmar pero no se pudo escribir. O vivir. Así, el estilo y la obra serían como la antimateria de una materia fantasma compuesta por todo aquello que no se hizo, que no se pudo hacer. 
Dejo para los especialistas y filólogos la aplicación de semejante concepto al estilo de Cervantes - tal cuestión excede mi capacidad- pero no puedo sino aplicarla al personaje de Cervantes. El Quijote no sería otra cosa que la traducción a novela de este síntoma un tanto psicótico: la voluntad de vivir y de protagonizar y cumplir el deseo de la vida, la fantasía en la realidad. Y, sí, es de esta voluntad tan épica como delirante, creo, que surge lo quijotesco, el virus, la fuga radiactiva, la fiebre, la alucinación, la epidemia y, last but not least, la ambigüedad. Porque Don Quijote es también Alonso Quijano. Y es, en principio, Quijano quien se deforma a sí mismo y se propone - enloquecido por la lectura de libros de caballeríaconvertirse en el definitivo paladín. El Quijote no es otra cosa que el sedimento real de esa ambición loca, lo que queda, lo que resulta, la sustancia despierta e insomne y cansada de ese sueño.

Así, el Quijote - lo quijotesco - es, por fin, la formidable innovación de la trama convertida en estilo. La digresión como forma y fondo narrativo. Digamos entonces que la novela digresiva asoma la cabeza - como Alien saltando desde el tórax de un organismo hasta entonces sencillo y frágil - ya en la primera novela moderna, en el Quijote de Cervantes. Don Quijote nace de una biblioteca y el Quijote es un libro hecho de libros y el Quijote es un personaje hecho de personajes. Y, ya que estamos en el asunto, una quijotesca digresión sobre el Quijote: ¿No será que todo eso que se le critica a la primera parte del Quijote — esa digresión en subtramas prescindibles y en novellas a saltarse - no es otra cosa que una tan hábil como genial maniobra y estrategia de Cervantes para volvernos adictos a su criatura, para que la amemos y la extrañemos y la necesitemos más y más y acabemos salteándonos páginas digresivas para buscar así reencontrarnos con el héroe?

\section{La naturaleza}

Y lo quijotesco es la naturaleza con todo lo que ello implica, con las múltiples facetas que pueden albergar sus letras. Porque a diferencia de lo que ocurre con los Beatles, con Kafka, con Picasso y con Fellini - protoadjetivos sin problemas a la hora de dirimir su signo-, lo quijotesco es más inasible, más ambiguo y, como muchos genes que inventan enfermedades, mucho más difícil de aislar y de contemplar a través de un microscopio de poderes telescópicos.

De este modo, ser quijotesco vale tanto como elogio e insulto, como virtud y defecto, como santidad y como idiotez. No es el Quijote - alguien felizmente perdido y encontrado en su auto-leyenda - quien determina su 
rango y poderío sino aquel que interactúa con el Quijote a lo largo de sus andanzas y lo calibra y, finalmente, abre y cierra un juicio sobre su persona y su personalidad. En Argentina tenemos una categoría que tipifica a la perfección el síndrome del Quijote: el "loco lindo". Y mucho depende del tiempo transcurrido junto a él o desde donde se lo mire. De cerca o de lejos.

Veamos: para muchos Zapatero es quijotesco, para muchos Osama Bin Laden es quijotesco, para muchos el Che Guevara es quijotesco, y yo escribiendo sobre el Quijote soy definitivamente quijotesco sin retorno. Las posibilidades y modelos son innumerables y más de una vez cualquiera de nosotros incurrió en una actitud irracional sintiéndonos redimidos y hasta justificados por el ejemplo del bueno de Quijano. Afortunadamente, el brote dura poco; pero - también hay que decirlo - resulta fácil volverse adicto al juego. Advertencia al consumidor y consulte a su farmacéutico: un Quijote en distantes dosis homeopáticas puede resultar simpático mientras que un Quijote extended play viviendo en el piso de al lado puede resultar agobiante. En resumen: al Quijote mejor leerlo que vivirlo; porque leyéndolo se lo vive.

Y leo también que Lord Byron - eximio internacionalista — sostenía que la decadencia del imperio español había comenzado con la publicación del Quijote. Byron - más irónico que convencido, creo- acusaba al monstruo de Cervantes de haberse corporizado como representativo Ser Nacional. El logotipo antropomórfico de la Naturaleza Ibérica y, por lo tanto, culpable de instruir y advertir con su potencia moral contra todo exceso de los sueños, de fantasías, de ser único y diferente. Para los españoles - según Byron - Don Quijote se había convertido en un cautionary tale cuando, en realidad, debería entenderse como un vive la différence. Así, Don Quijote como aleccionador sinónimo de caerse una y otra vez del caballo de la fantasía para ir a dar con los huesos al durísimo suelo del muy verdadero ridículo. Don Quijote casi como uno de esos comerciales contra la droga o contra el conducir a alta velocidad donde se pregunta a los padres si saben dónde y con quién están sus hijos en esta noche larga y oscura. Don Quijote como aquello que te puede llegar a ocurrir si te pasas de la raya y del semáforo. Así, si — según el grabado de Goya — "el sueño de la razón produce monstruos"; entonces, cuando de la novela de Cervantes se trata, "el sueño de lo irracional produce Quijotes".

Está claro que Byron no se creía demasiado lo que dijo y me pregunto qué hubiera dicho Byron de Martín Fierro, ese tortuoso y rimado y trágico y multiétnico gaucho errante que funciona como equivalente de la criatura de Cervantes - a la hora de héroe patrio - para los argentinos. Está claro que lo férreo poco y nada tiene que ver con lo quijotesco y donde el 
caballero de la triste figura es un alegre alucinado el melancólico gaucho que pregona aquello de "los hermanos sean unidos" en realidad sólo piensa en ir por la suya, y sálvese quien pueda, y a mí no me miren. Martín Fierro y Don Quijote jamás se habrían llevado bien. Voltaje irreconciliable de egos, diferencias insalvables de carácter.

Y escribo esta última frase $\mathrm{y}$, de golpe, una súbita y presente intromisión de lo quijotesco, en vivo y en directo, y bastardeado por la pantalla de lo catódico y lo trash, en mi televisor.

Veamos, temblemos:

Un quijotesco programa de televisión llamado Gran Hermano. ¿Qué tiene que ver este engendro con la novela de Cervantes? Pienso que bastante; porque no hace otra cosa que proponer la existencia de un mundo irreal intersectando con la realidad desde la que lo contemplamos sin poder creerlo del todo.

Pero, claro, en verdad todo tiene algo que ver con la novela de Cervantes, porque he ahí el mérito y el poderío de los grandes libros: el de, a partir de una ficción particular, relacionarse sin problemas con la no-ficción universal, estar en todas partes, entrometerse con éxito más allá de sutilezas de traducción.

En cualquier caso, ahora, mientras escribo esto, en Gran Hermano, un tal Juanjo corteja a una tal Diana. Juanjo es un ser extraño y de doble vida: durante el día es taxista y por las noches se convierte en un eximio bailarín de salsa. O algo así. Un consumado Quijote. Diana, por su parte, es una estilizada modelo catalana que habla rápido y piensa despacio y raro, y que no pierde la sonrisa ni siquiera cuando se ve obligada a palear mierda de vaca frente a las cámaras mientras se pregunta qué pensarán sus amigas. En cualquier caso, todo parece indicar que Juanjo se ha encaprichado con Diana, y Diana lo deja hacer porque ya está acostumbrada a estas cosas: a que la miren y a que la deseen sin que ella tenga que hacer nada. Está claro que Juanjo acabará con el corazón roto y buscando consuelo en algún antro de falsa estética tropical. Diana, por su parte, recordará todo esto como un sueño o una pesadilla en su pisito de Sarriá y, a su salida, su rostro y su cuerpo cotizarán mejor a la hora de castings y bookings de pasarela. Pero no importa, todavía falta mucho para eso, y tanto Gran Hermano como Don Quijote - ya lo dije - gozan del tiempo en suspensión a la hora de generar y habitar una realidad aparte. Así que ahora - veo esta escena con una mezcla de horror y fascinación - Juanjo persigue a Diana entre vacas y montañas de heno y de mierda y que es lo que grita Juanjo con toda la fuerza de sus pulmones. Aunque ustedes no lo crean - el hombre también ha sido contagiado por más que, es posible, jamás haya 
tenido la novela de Cervantes entre sus zarpas - lo que grita Juanjo es: “¡Dulcinea! ¡Mi Dulcinea! ¡No huyas, mi Dulcinea!”

\section{Génesis y apocalipsis}

Y, sí, el estilo de Don Quijote - como el de Juanjo- es decididamente anti-heroico y fundante a la hora de la victoria perdedora. Pensar en el Quijote como en una épica del fracaso, pero épica al fin; en la triste figura de un caballero como apología de la derrota pero, también, como burla y alternativa a lo que ya comienza a ser -incluso a principios del siglo XVII - la cultura del éxito. Pensar en el Quijote como en un libro triste pero gracioso y como en una novela profunda pero entretenida. A esto se refiere Milan Kundera - a este comienzo auspicioso de lo moderno donde nada está del todo asentado, donde quedan atrás el blanco y el negro para que lleguen las tan gratificantes como inquietantes hordas de grises- cuando señala a Cervantes como "padre de la gran novela europea; alguien que no pierde de vista la idea y la creencia que sólo en lo entretenido pueden dirimirse las grandes cuestiones serias".

Por eso, de ahí, que Cervantes plante al tragicómico Quijote con inequívocos modales de dios Shiva. Cervantes baila escribiendo y, en su danza, comulgan las polaridades de la creación y de la destrucción. El Quijote es una línea flaca pero fuerte, un límite definitorio y definitivo, una frontera que una vez cruzada no ofrece pasaje ni paisaje de vuelta: de un lado queda la gloriosa tradición de la literatura de caballería y hazaña pura, del otro surgen los efectos de esa literatura - de esas ficciones- sobre los territorios de la realidad. Y el Quijote y lo quijotesco — implacables — se las arreglan para funcionar como funcionan las vacunas: atacan al virus con el virus (recordar que finalmente Don Quijote es vencido por una escenificación terapéutica de su propia locura: el bachiller Sansón Carrasco disfrazado como el Caballero de la Blanca Luna, quien antes fue el Caballero de los Espejos) pero, en lugar de neutralizarlo, lo potencian convirtiéndolo en otra cosa, en algo novedoso por entonces, en algo que sigue siendo original. Riéndose del Tirant lo Blanc y del Amadís de Gaula (libros que el cura párroco salva del holocausto de la biblioteca de Quijano acaso por considerarlos fundantes), Cervantes — quien respeta a estas obras cuanto más se alejan de los lugares comunes del género y que, otra novedad atendible, valora a los libros en cuanto a libros y no en cuanto al valor de sus héroes - no hace otra cosa que aquello que se les permite a y que se pueden permitir los más originales revolucionarios de cualquier sistema: encandilar un crepúsculo con los fulgores de un nuevo amanecer. 
Así Cervantes - amparado por la gracia que le concede la figura/ estandarte de un perdedor que se niega a distinguir entre los libros y la vida y que quiere encontrar el mito fuera de los libros - triunfa y patea el tablero y cambia las reglas del juego para siempre proponiendo un nuevo plano de lectura. Un flamante sistema literario. Un subgénero que - siguiendo dictados darwinianos - no demora en combatir y vencer y devorar hasta la extinción a aquel género del que supo surgir. Pensar entonces en Tirant lo Blanc y en Amadís de Gaula como en dinosaurios. Pensar en el Quijote como en ese meteoro que viene de un espacio más interior que exterior pero que, lo mismo, acaba incrustándose contra la superficie del planeta y adiós a todo eso. Apocalipsis ahora y siempre.

Leyendo al Quijote, leemos al mismo tiempo todo lo que el Quijote leyó y el efecto que esas lecturas causaron en él. Y leemos también el modo en que estas lecturas produjeron en Cervantes la necesidad de releerlas al reescribirlas. Así también, el Quijote como una novela donde se queman novelas y que, al mismo tiempo, es en sí misma una hoguera donde arden las viejas tradiciones para construir un nuevo orden sobre sus restos. Ruinas donde, enseguida, florece la paradoja: la saga verdadera pero al mismo tiempo imaginaria - la trama del Quijote acontece en dos planos simultáneos: lo que sucede y lo que el Quijote cree que sucede- donde un hombre huye de la realidad en busca de una quimera a la vez que intenta trasplantar esa quimera a la realidad de este mundo. Nadie había escrito o ha vuelto a escribir historia más auténticamente heroica que ésta: la historia de un organismo que se sacrifica para que evolucione toda la especie y, como precisa Borges, acaba siendo "menos un antídoto de esas ficciones que una despedida nostálgica".

Otra vez: Cervantes sólo puede y consigue curar las taras físicas de la novela antigua con la invención de los complejos psicológicos de la novela moderna; y en los ensayos reunidos en Por Qué leer a los clásicos, el escritor Ítalo Calvino lo diagnostica y se pregunta: “¿Cuál será la suerte del mundo novelesco de la caballería cuando el espíritu analítico intervenga para establecer los límites entre el reino de lo maravilloso, el reino de los valores morales, el reino de la realidad verosímil?" Y Calvino se responde: "La repentina y grandiosa catástrofe en la que el mito de la caballería se disuelve en los asoleados caminos de La Mancha es un acontecimiento de alcance universal, pero que no tiene análogos en las otras literaturas".

$\mathrm{Y}$ es cierto.

Pensar en todos los grandes libros de todos los grandes lugares de cuyos nombres nos acordamos. Ahí están y ahí seguirán estando. Su inmortalidad está garantizada. Pero, sin embargo, su calidad es diferente. Pen- 
semos, por ejemplo, en los grandes innovadores del siglo XX. Pensemos en Proust y en Kafka y en Joyce y en Hemingway y en Borges; en autores que también cierran lo que fue y abren lo que vendrá pero que, sin embargo, parecen acabar en sí mismos, porque todo reflejo de continuarlos - a diferencia de lo que ocurre con Cervantes y quienes lo precedieron y de quienes él se aprovecha- tropieza y cae no en la parodia voluntaria sino en ese horror sin disculpa que es la parodia involuntaria. Estos son autores invocados no a través de su destrucción sino de su conservación.

Cervantes, por lo contrario, innova para influir, escribe rápido y sucio para contaminar y así la idea de lo quijotesco alcanza y envuelve hasta a los más originales; porque hay algo de quijotesco en los celos de Marcel, en la metamorfosis de Samsa, en los paseos de Bloom y de Dedalus, en la lucha de Santiago contra el pez espada y los tiburones y, claro, hablaré de esto más adelante, en el original copista Pierre Menard de Borges.

Del mismo modo, la respiración y el latido del Quijote se sienten en los adúlteros pechos de Anna Karenina y Madame Bovary, en las jamesianas "locuras del arte" que poseen a Gulley Jimson en La boca del caballo y a Ignatius Reilly en La conjura de los necios, en las aguas dulces y saladas donde flotan y se hunden Huck Finn y Ahab, en los endemoniados y los idiotas de Dostoievsky, en todos esos pícaros ingleses del siglo XVIII como Tom Jones y Tristram Shandy y — cada vez más lejos y cada vez más cerca - en los peripatéticos indios cosmopolitas de Salman Rushdie o en los argentinos campeones desparejos y juguetes rabiosos de Bioy Casares o Arlt. Y siguen los nombres y las firmas: el Lucas de Cortázar, el Martín Romaña de Bryce Echenique, el Kurtz de Conrad, el T. S. Garp de Irving, el Hombrevida y los poetas anarcos de Chesterton (quien, atención, escribió una última novela titulada El regreso de Don Quijote donde el protagonista es un bibliotecario enloquecido por las maquinarias de la Edad Industrial mientras sueña con un retorno a la unplugged Edad Media), el Jay Gatsby de Fitzgerald, el Augie March de Bellow, el Leander Wapshot de Cheever, el cónsul Firmin de Lowry, el Seymour Glass de Salinger, el Billy Pilgrim de Vonnegut, todos esos autistas automáticos de Beckett, el Monseñor Quijote de Graham Greene, la deconstrucción surreal-posmoderna-porno del Don Quixote de Kathy Acker, y en esa curiosa inversión de sexo que propone Charlotte Lennox en The Female Quixote, or the Adventures of Arabella donde la heroína, al igual que la ya mencionada Emma Bovary, es una adicta enloquecida a las novelas románticas.

¿Qué tienen todos ellos en común con el monstruo de Cervantes? Sencillo, la misma enfermedad - el mismo adjetivo en préstamo funcionando como blanda armadura - que los contagia y los autoriza a plantarse 
como hombres y mujeres con una misión y, al mismo tiempo, sumisos a esa misión. Se me ocurre un término para todos ellos: damas y caballeros sumisionados. Seres deslumbrados por un ideal privado al que no pueden sino obedecer. Iluminados como los quijotescos pre-quijotes que bien pudieron ser todos esos profetas del Antiguo Testamento y Jesús en el Nuevo Testamento y más de un arquetípico dios o semidiós de mitos ancestrales de libros desaparecidos para siempre en las llamas de la Biblioteca de Alejandría. La diferencia con ellos - lo que hace del Quijote un héroe moderno y lo que lo vuelve tan contagioso- es que su misión no aparece dictada por mandato divino o instancias superiores. Su misión es suya y nada más que suya y empieza y termina en él mismo. Nadie más adora a Dulcinea, nadie más ve gigantes donde hay molinos. Su religión y su cruzada son la de un solo pero tan apasionado fiel. De ahí que — en el contexto de la novelaDon Quijote sea el primer incomprendido por los suyos y, desde aquí, el único que comprendemos nosotros junto - de tanto en tanto- a ese emba-

jador nuestro en las páginas de la novela de Cervantes que se llama Sancho Panza.

\section{El otro}

Sancho Panza, el otro, somos nosotros porque - a medida que transcurre la novela - Sancho Panza lee a Don Quijote con ojos que son, de algún modo, los nuestros. Sancho es el lector, el acompañante, el testigo, ese stendhaliano espejo camino abajo en el que se mira el héroe para mirarnos a nosotros. Si la lectura de toda novela equivale a la paciente supresión de nuestra persona y nuestras vidas para así hacer espacio para que entren otras vidas y otras personas; entonces lo que ocurre con Sancho Panza en la novela de Cervantes es diferente. Sancho Panza funciona como punto de vista a la vez que pared más o menos amiga donde rebota una y otra vez el Quijote. La dupla Quijote/Sancho es, de algún modo, la génesis de las grandes parejas de cómicos y de esas buddy movies con policías opuestos pero complementarios. Uno y otro - Yin y Yang - como generadores de todas esas rutinas basadas en la pelea, la reconciliación y en un amor diferente pero a prueba de toda desgracia. Uno y otro como duelo de lenguajes: la retórica arcaica y caballeresca del Quijote versus la dialéctica presente y práctica de Sancho.

La existencia de Sancho es lo que hace diferente al Quijote como novela. La teoría y la práctica de que - a diferencia de lo que ocurre con buena parte de las otras novelas ya citadas - el héroe de Cervantes sabe que necesita al otro para ser uno, para perpetuarse, para poder ser narrado y 
leído y mitificado. El Quijote es único y Sancho Panza es todos los demás y es, además, víctima del contagio de la "enfermedad" de su señor en la segunda parte del libro. Y es así como, infectado y feliz, acaba casi protagonizándolo y convirtiéndose en el motor responsable de muchas de sus acciones. En la novela, Sancho Panza empieza cuerdo y va enloqueciendo progresivamente mientras que Quijano empieza loco y va acercándose de a poco a la cordura. En algún momento, se encuentran a mitad de camino y, por un instante, son iguales, idénticos, plenos. Y entre los dos — la cabeza en las nubes de uno y los pies en la tierra del otro- acaban comprendiendo y encapsulando aquello que, a falta de un mejor nombre, hemos dado en llamar "la condición humana".

\section{Idea para una novela policial}

En la conflictiva pero nutricia relación entre Sherlock Holmes y Watson se oye sin dificultades el eco del vínculo que unió a Don Quijote con Sancho Panza. Los caracteres están mezclados y confundidos, es cierto; pero el aliento y la intención son los mismos. Uno para otro y otro para uno. En una posible novela policial, Don Quijote no fallece consumido y sin energías luego de haber "caído malo" sino, lo descubre sin demora el Bachiller, ha muerto envenenado. El asesino, por supuesto, es Sancho Panza -el asesino es siempre el mayordomo - quien no soporta que su amo y señor haya recuperado la razón y vuelva a ser el mismo aburrido de siempre. Sancho Panza se ha vuelto loco, se cree Don Quijote, y es prontamente encerrado en la celda de una casa de locos.

$\mathrm{Y}$ uno de esos misterios históricos o histéricos en el que recién ahora reparo. Una tontería que no lo es tanto y que revela unas cuantas cosas, supongo. A la hora de películas y cómics y chistes y esas cosas, suele poblarse a los manicomios con Napoleones. Creerse Napoleón - creerse un guerrero verídico, un emperador real- es síntoma inequívoco de locura. Es el cliché del estar loco. Curiosamente, no conozco habitante de loquero alguno - real o imaginario - que esté allí por creerse Quijote. ¿Por qué esta ausencia de lógica a la hora de perder el sentido de lo lógico? ¿No deberían los manicomios estar repletos de Quijotes más que de Napoleones?

Sólo se me ocurre una explicación para esto: creerse otro, otro que existió y cuya carrera desborda éxitos y hazañas, es de locos. Creerse alguien nuevo y épicamente perdedor es algo o alguien que nadie quiere creerse. Ni siquiera los locos, tal vez más interesados en sentirse genios 
estratégicos y emperadores todopoderosos. Para creerse Quijote hay que ser Quijote. Y hay que estar siempre afuera y nunca entre desquiciados. En este sentido - y a la hora de la patología manicomial — un Quijote encerrado no tiene sentido alguno. No tiene razón de ser. En su conferencia "El Quijote, una lectura fronteriza", el escritor mexicano Juan Villoro apunta: "Cuando a Barry Gifford le preguntaron acerca de la evidente influencia de la novela En el camino, de Jack Kerouac, en su obra Corazón salvaje, respondió que todas las road novels provenían del Quijote. Cervantes funda por partida doble la novela moderna y el subgénero de la novela nómada que llega hasta Los detectives salvajes, de Roberto Bolaño, donde Ulises Lima y Arturo Belano, aprendices de poetas, emprenden una errancia al modo cervantino pero en sentido inverso a Don Quijote: no buscan que la vida compruebe lo que leyeron en los libros; viven para investigar la materia que puede ser poesía. A bordo de un desvencijado Impala, recorren el norte de México rumbo a la zona de indefinición, lo híbrido, la frontera tex-mex.

Como ocurre con las cabalgaduras del Quijote, el coche donde los poetas viajan con las melenas al viento debe ser inseguro para potenciar las incertidumbres de la trama. Thelma \& Louise, de Ridley Scott, representa una versión exacerbada del tema, con una pareja de mujeres por protagonistas, donde la errancia en autos robados es una huida y la última frontera un salto al abismo, única opción de no volver a la restrictiva realidad. Don Quijote es un lector metido a hombre de acción; sus lances se fundan en causas moralmente válidas, pero al no distinguir lo real de las figuraciones, rozan el abuso y el delito. Esta disparidad entre las convicciones y su transformación en hechos, se expresa con nitidez en el discurso sobre las armas y las letras, acaso el pasaje en el que Cervantes se despoja con mayor holgura de su juego de suplantaciones y habla por sí mismo en boca de Don Quijote. El escritor soldado lamenta la triste recompensa que reciben quienes ponen su vida en prenda y lo difícil que resulta mostrar la valentía individual en una era que cuenta con "endemoniados instrumentos de artillería". El lance solitario del caballero que obra por convicción es ya imposible. El anacronismo representado por el Caballero de la Triste Figura se expresa también por el hecho de que busca llevar sus ideales a la acción. La defensa de las armas tiene un tono nostálgico; Cervantes sabe que ya son inviables, pero no se resigna a transformar la realidad. Varios siglos después, el detective establecería en la cultura popular una sugerente mediación entre la investigación de la realidad (la deducción intelectual) y la acción".

Y para seguir en los territorios sin mapa de lo alucinado y de lo detectivesco, se me ocurre una buena manera de sintetizar a la novela de 
Cervantes. Aquí va; y pensemos entonces en el Quijote como en una suerte de thriller espiritual protagonizado por un detective todavía más solipsista que el ya mencionado Sherlock Holmes. Algo así: en el Quijote alguien busca su razón de ser mientras pierde la razón y, al recuperar su razón, pierde su razón de ser.

Y, por lo tanto, se muere.

La cuestión es si muere feliz o no. Una cosa queda clara: en la novela, Don Quijote muere cuerdo, recuperado, montando con firmeza el caballo de la realidad. Pero reconvertido en el real y agonizante Alonso Quijano el Bueno, Don Quijote muere antes. El efecto sería siglos más tarde revisitado por Stevenson para el final del Dr. Jekyll, otro personaje dual obligado a cargar casi hasta su último aliento al peso karmático de Mr. Hyde.

\section{Los otros}

Stendhal, luego de leer el Quijote, destila en sus Diarios, lo que el considera como las inevitables cinco reglas de la literatura a la hora de lo que ya intuye deber ser lo que hoy conocemos como Novela Total. Ese libro que - al igual que las pinturas rupestres en las cuevas de Altamira en las que ya se detectan las líneas y los trazos de la abstracción de lo moderno- acabará sin tiempo ni espacio porque acabará estando en todas partes $\mathrm{y}$ a toda hora.

Las reglas de Stendhal son las que siguen:

1. No puedes describir aquello que nunca has visto.

2. Lo sublime, tenerle simpatía a un poder que, por lo general, entendemos como algo terrible.

3. La risa.

4. La sonrisa, paisaje de la felicidad.

5. Estudiar la pasión en los manuales de medicina, en la naturale$z a$, en las artes.

Stendhal recomienda, también, por supuesto, la lectura de Shakespeare como complemento nutricional y vitamínico. Pero vuelve sobre el Quijote y lo más interesante de todo es lo que Stendhal agrega: "Las pasiones no pueden emerger del pecho de quienes no son apasionados. Para retratarlas, hay que primero sentirlas". Lo que implica, de algún modo, una clara justificación de la naturaleza quijotesca no ligándola al diagnóstico de una patología sino, por el contrario, reformulándola como remedio inevitable a la 
hora de adquirir conocimientos. Hay que vivir - como Cervantes - antes que escribir. Hay que moverse antes de asentarse y, por eso, el Quijote es una inequívoca road-novel donde no sólo viajan los cuerpos sino que también lo hacen las mentes. Después, ya lo dije, por supuesto, Stendhal menciona a Shakespeare.

Cuando se habla de Cervantes, Shakespeare siempre es el otro. Supongo que sucederá lo mismo cuando se habla de Shakespeare: rebota el reflejo de Cervantes. En una u otra situación, la aparición de ambos nombres está siempre justificada y no me parece inapropiado que el autor del Quijote y el autor de Hamlet - variaciones muy diferentes sobre una misma aria- hayan tenido la tan simbólica como legítima gentileza de haber muerto el mismo día: el 23 de abril de 1616, día de San Jorge. Aunque en verdad una diferencia entre almanaques ibéricos y británicos separe sus últimos alientos en diez días. No importa. Minucias. Lo que sí importa es que poco y nada cuesta pensarlos pensándose como agentes patógenos de alto poder y de veloz propagación que seguirían vivos y coleando en todos los que vendrían después de ellos. Así que vámonos.

Y viene Nabokov, claro. Nabokov — creador de los quijotescos Pnin y Humbert Humbert - tiene problemas con el Quijote y a su triste figura le dedicó clases alegres que luego de su muerte fueron recopiladas en un libro donde se lucha contra la criatura de Cervantes para acabar, resignado, contagiado por ella. Para que no queden dudas, Nabokov establece desde el principio que toda comparación del nivel del mar de Cervantes con las alturas inalcanzables de Shakespeare es absurda; aunque ambos - término casi médico- sean iguales de poderosos a la hora de la "irrigación espiritual" en los escritores que los sucederían. Para Nabokov, el Quijote es desprolijo, está escrito con inusual torpeza, abunda en incongruencias espacio/temporales, en chistes sin gracia y en repeticiones que denuncian que Cervantes escribió como poseído o, sencillamente, apurado o, tal vez, tan enloquecido como su héroe. "Uno de esos libros que quizá sea más importante por su difusión excéntrica que por su valor intrínseco", concluye. Y agrega algo que me parece pertinente citar aquí porque subraya claramente el carácter virósico del asunto: "Estamos ante un fenómeno interesante: un héroe literario que poco a poco va perdiendo contacto con el libro que lo hizo nacer; que abandona su patria, que abandona el escritorio de su creador y vaga por los espacios después de vagar por España".

Así, el Quijote como esas esporas maléficas y extraterrestres de ciertas paranoicas películas clase B de los años 50. Así, el Quijote que no se lee porque se conoce. 
Otros testimonios pertinentes:

El siempre conciliador Harold Bloom - empeñado en su quijotesco afán de leerlo todo - propone: “¿Por qué leer el Quijote? Porque sigue siendo la mejor novela, y la primera, del mismo modo en que Shakespeare sigue siendo el mejor dramaturgo".

Anthony Burgess - autor del quijotesco y ultraviolento Alex de $L a$ naranja mecánica - ofrece una versión alternativa del duelo de titanes con forma de cuento donde se rescribe la Historia. En "A Meeting at Valladolid", incluido en el libro The Devil's Mode (1989), el escritor británico hace coincidir a Cervantes y a Shakespeare en un festival artístico. Uno y otro no se llevan demasiado bien y hasta se acusan de plagiarios mutuos. Un intérprete llamado Don Manuel de Pulgar Garganta es quien, finalmente, dirime la cuestión y falla a favor de Cervantes no en nombre del fondo sino de la forma. Al final del relato, Shakespeare - de quien se dice llegó a escribir The History of Cardenio, una comedia perdida e inspirada en un personaje secundario del Quijote - reconoce la supremacía de la comedia sobre la tragedia, aligera a su Hamlet pero lo prolonga hasta siete horas y lo infecta de bromas y carcajadas con el añadido de un Falstaff funcionando como sucedáneo de Sancho. El final muestra al príncipe sombrío partiéndose de risa, muy lejos del suicidio, y reinando feliz en una Dinamarca donde lo que alguna vez olió a podrido ahora huele a rosas. Don Manuel de Pulgar Garganta argumenta que la novela es el futuro y el divertimento teatral es un presente poco práctico y limitado en sus movimientos. De acuerdo: Hamlet puede ser más profundo y estar mejor escrito que el Quijote, pero el Quijote flota y fluye mejor que Hamlet.

Y a la hora de no de zanjar el conflicto pero sí de alcanzar una tregua sin fecha de vencimiento propongo lo que sigue. Si para Shakespeare "todo el mundo es un escenario" (un espacio prohibido al que sólo se puede ver desde afuera); entonces para Cervantes todo el mundo es una biblioteca", un espacio público y abierto. Y ya saben: no hay nada más imposible y quijotesco que la idea de mantener una biblioteca en orden. Una obra de teatro empieza y termina; mientras que una novela siempre sigue y siempre será nuestra y sólo nuestra. Comparado con la docilidad a la que se rinde el espectador de teatro, el acto de la lectura - esa ceremonia íntima donde las letras se funden en imágenes que exigen diversas profundidades de campo y encuadres y ángulos y actores- implica una opción diferente donde lo que importa es la diferencia. La literatura es la más democrática de las artes y así es que hay tantos Quijotes diferentes como lectores del Quijote haya; por más que el libro que se sostiene entre las manos sea siempre el mismo. Borges lleva este gozoso trastorno a su extremo absoluto cuando escribe un relato titulado "Pierre Menard, autor de El Quijote" donde la reescritura 
exacta de Cervantes deviene en una novela nueva y contemporánea de su nuevo y orgulloso y genial autor.

\section{La biblioteca}

Ya lo dije: Don Quijote nace de una biblioteca y el Quijote es un libro hecho de libros. Y todos tienen su capítulo favorito del Quijote, como todos vuelven una y otra vez a un salmo o a un hexagrama o a una sura. Y en los últimos días, a medida que me iba enfermando por una sobre exposición a la novela de Cervantes (los síntomas fueron unas llagas en la lengua que ahora dificultan mi lectura de estas páginas) y a la figura del Quijote (que se me aparecía en las formas más inesperadas: un cuadro de Edward Hopper que nunca había conocido, una foto de Warhol y Burroughs almorzando en un restaurante de New York llamado El Quijote; en la llamada telefónica de una amiga ilustradora que me comentaba que estaba preparando "un Quijote para niños de 0 a 3 años") leí un viejo ensayo de Borges sobre el capítulo 22 y otro no tan antiguo de Bolaño donde evoca aquel capítulo donde se discuten los méritos de la milicia y la poesía.

Dice Borges: "Cotejado con los libros clásicos (La Ilíada, La Eneida, La Farsalia, la Comedia dantesca, las tragedias y comedias de Shakespeare), el Quijote es realista: este realismo, sin embargo, difiere esencialmente del que ejerció el siglo XIX. Joseph Conrad pudo escribir que excluía de su obra lo sobrenatural, porque admitirlo parecía negar que lo cotidiano fuera maravilloso: ignoro si Miguel de Cervantes compartió esa intuición, pero sé que la forma del Quijote le hizo contraponer a un mundo imaginario poético, un mundo real prosaico".

Dice Bolaño, en el contexto de una elección de la milicia por encima de la poesía, de la milicia como sinónimo de juventud y de lucha, de sus viejas batallas: "Cervantes es el más lúcido, pues él sabe que los escritores no necesitan que nadie les ensalce el oficio. Nos lo ensalzamos nosotros mismos. A menudo nuestra forma de ensalzarlo es maldecir la mala hora en que decidimos ser escritores, pero por regla general más bien aplaudimos y bailamos cuando estamos solos, pues éste es un oficio solitario, y recitamos para nosotros mismos nuestras páginas y ésa es la forma de ensalzarnos y no necesitamos que nadie nos diga lo que tenemos que hacer y mucho menos que tras una encuesta nuestro oficio sea elegido el más hermoso de todos los oficios ... La literatura es un oficio peligroso".

¿Cuál es mi capítulo favorito? En realidad son varios pero entre los tres completan el rasgo del Quijote que más me ha contaminado a mí. Me refiero a esos momentos en los que Cervantes se pone metaficcional. El capítulo 6 en el que el cura y el barbero inspeccionan la biblioteca de Quija- 
no y encuentran un libro de Cervantes y hablan bastante mal del mismo diciendo que "propone algo y no concluye nada"; el capítulo 9 donde se nos revela que el mismo Cervantes encuentra en Toledo el manuscrito original de la novela, escrita en árabe por un tal Cide Hamete Benengeli, y la manda a traducir sin demora; el capítulo 50 en el que Don Quijote comenta y defiende los libros de caballería; y los capítulos 2, 3 y 4 de la segunda parte donde el bachiller Sansón Carrasco y Sancho y Don Quijote comentan la existencia de una primera parte del Quijote y de lo que de ella y de ellos piensan los lectores. En el capítulo 70 de la segunda parte - muy cerca del final- el fenómeno se hace todavía más inquietante: la hermosa Altisidora les cuenta al Quijote y a Sancho que, mientras fue víctima de un hechizo, llegó a ver a varios demonios jugando a la pelota con libros y, entre ellos, un ejemplar de la mismísima segunda parte del Quijote. Altisidora les cuenta que uno de los demonios, un demonio crítico, lo define como "tan malo que si de propósito yo mismo me pusiere a hacerle peor, no acertara".

Así - y esto me parece verdaderamente interesante- el Quijote acaba contagiándose de sí mismo. La idea — la maniobra metaficcional— no era nueva porque ya aparecían autorreferencias en textos épico-religiosos como el Ramayana, en algún episodio de Las mil y una noches y en ese formidable final del Orlando de Ariosto cuando, en el último de sus cantos, se nos describe a una multitud en un muelle esperando la llegada del héroe y esa multitud está compuesta por amigos de Ariosto: sus lectores ideales quienes han venido siguiendo las hazañas del héroe y se disponen a celebrar el final de la aventura.

La novela de Cervantes lleva todo esto más lejos y — si bien el genio de Shakespeare está mejor escrito y también Hamlet incluye en sus entrañas una representación de sí misma - lo cierto es que la muerte del príncipe de Dinamarca nunca nos emocionará tanto como la muerte del noble de La Mancha. La muerte de Hamlet no ofrece dudas. La muerte del Quijote funciona tanto como final triste o final feliz y su humor depende, exclusivamente, del momento por el que estemos pasando, de nuestra circunstancial fuerza o debilidad ante el embate del virus.

\section{Idea para una comedia musical}

En realidad, esta idea ya se le ocurrió a otro y se titula El hombre de La Mancha y allí Peter O'Toole - tembloroso y genial actor especializado en personajes quijotescos como Lawrence de Arabia y Lord Jim y Mr. Chips - canta y baila y mira fijo los rotundos pechos de Sofía Loren. A mí la película, basada en un éxito de Broadway, me gustó mucho cuando la vi — era un niño- y me siguió gustando cuando volví a verla días atrás. La 
película, para empezar, tiene el mérito de haber sido estrenada. Porque no es fácil llevar el Quijote al cine — por más que Cervantes ya haya recurrido a esa hollywoodense maniobra de una primera y una segunda parte- $-\mathrm{y}$ si no pregúntenselo a Orson Welles (y lean un excelente ensayo de Jorge Volpi en la revista Letras Libres* sobre este descalabro) o a Terry Gilliam (y vean el excelente documental sobre este otro descalabro titulado Lost in La Mancha) y en alguna parte leí que hasta Fellini pensó en filmar la novela de Cervantes con Jacques Tati en el rol protagónico pero, al final, optó por el quijotesco Marcello de La Dolce Vita.

La primera visión de El hombre de La Mancha fue mi segunda exposición al mito cervantino y me gustó - recién ahora lo comprendo- que el musical profundizara en la naturaleza metaficcional de la novela que no leería sino hasta muchos años después. En El hombre de La Mancha, O'Toole hace de Cervantes que hace de Don Quijote durante su estancia en la cárcel donde para salvar el pellejo seduce como una Scherezade a los asesinos allí recluidos y les otorga diferentes papeles en una puesta teatral privada y minimalista de su novela que enseguida, por obra y magia del Cinemascope, sale a exteriores y entonces música y versos y romance y un detalle importante que - blasfemia para muchos, emoción para mí- deforma o reforma el mito. En el último minuto de El hombre de La Mancha, justo antes de morir, el cuerdo Quijano vuelve a convertirse por un instante, en el alucinado Quijote. Y canta. Y después se muere. Y yo creí entonces y sigo creyendo ahora que es un final más feliz e igual de amargo. Un final tan agridulce como el de ese otro Quijote que es el sufrido George Bailey - caballero andante condenado a no poder abandonar su pueblo- en ¡Qué bello es vivir! de Frank Capra.

\section{El lector}

El lector soy yo. Y recién dije que mi segunda exposición a Don Quijote fue cinematográfica. La primera fue televisiva. En el Buenos Aires en blanco y negro de mi infancia, los domingos por la noche se emitía un programa de televisión titulado Titanes en el Ring y donde se predicaba con alma y músculo el evangelio de la lucha libre y de los luchadores enmascarados con nombres históricos como Sansón, El Mosquetero, Drácula, Mercenario Joe (una especie de guerrillero à la Fidel Castro), La Momia y, por supuesto, Don Quijote. Su llegada al cuadrilátero estaba anunciada, siempre, por una canción/slogan —entonado por trémulas y lánguidas voces símil monjes gregorianos- donde se oía: "Don Quijote y Sancho Pan-

* Reproducido en esta edición de Estudios Públicos. (N. del E.) 
za / Van en pos de la justicia / Van en pos de la esperanza / Don Quijote y Sancho Panza". O algo así. Don Quijote vestía una armadura de caucho plateado, llevaba lanza y casco, era flaco y alto, era puntualmente molido a golpes, perdía siempre, y tenía que ser rescatado por un rotundo Sancho que peleaba dando contundentes panzazos haciendo honor a su anatomía y su apellido. A veces aquel Don Quijote daba tanta pena, que gente como El Extraterrestre o el Caballero Rojo - triunfadores siempre - salían en su defensa. Tengo que decir que Hamlet —un luchador pálido y siempre con la calavera a mano- jamás se subió al ring a ayudarlo.

En cualquier caso, este sufrido Quijote me provocó la curiosidad suficiente como para - luego de haber visto la ya citada película - intentar la lectura de la novela. Yo era un niño que ya quería ser escritor y, por eso, opté por la versión original y no por alguna de esas versiones para jóvenes convenientemente adaptadas y modernizadas y con ilustraciones que no estaban firmadas por Gustave Doré, claro. Está de más decir que reboté sin gracia alguna contra las aspas de la primera página y caí de mi cabalgadura. Suele ocurrir. Los grandes libros nos rechazan hasta que nos sienten dignos de ellos o hasta que, resignados, comprenden que jamás estaremos a su altura; así que mejor algo que nada. Entonces nos abren a nosotros mientras nosotros pensamos que los abrimos.

Leí por fin El ingenioso hidalgo don Quijote de la Mancha (1605) y El ingenioso caballero don Quijote de la Mancha (1615) durante mi servicio militar obligatorio (1984) y a lo largo de lentas guardias nocturnas que, en mi cada vez más quijotesco país de origen, llevan el muy cervantino nombre de imaginarias. Me acuerdo que por esos días - y por esas noches- el Quijote también había sido protagonista de un enorme escándalo: el intendente militar de la ciudad de Buenos Aires había plantado una horripilante estatua del Quijote en la intersección de la Avenida 9 de Julio con la hispanísima Avenida de Mayo. La estatua sigue estando allí y es atroz y muestra a un Quijote y a un Rocinante como emergiendo de una montaña de helado de vainilla. De acuerdo: suena raro. Pero es que es muy difícil describirla. Hay que verla para creerla.

Me recuerdo entonces, en una caseta de hormigón armado, escuchando los ruidos que hacía un quijotesco sargento disfrazado del fantasma de un soldado muerto en las islas Malvinas para así, me dijo cuando descubrí su trampa, "mantenerlo vivo a él y despiertos a ustedes". Me acuerdo que una noche ese sargento me preguntó que leía y le mostré la portada y me cantó de principio a fin la canción del Quijote de Titanes en el Ring y después me preguntó por qué leía libros tan tristes. Le pregunté si lo había leído. Me respondió que no, pero que sabía de qué trataba. Y, como prueba de ello, me ofreció una versión condensada de menos cinco minutos. Era un 
resumen completo en la trama pero, claro, insalvable en su falta de matices y de gracia y doloroso en su desprecio por el protagonista.

Le comenté esto, le dije que no me parecía correcto.

El sargento me miró fijo y, después, me ordenó que diera diez vueltas a la pista de combate.

Arrastrándome.

“Como Don Quijote", precisó sonriendo el sargento.

\section{Idea para un micro-relato}

O para una de esas ficciones súbitas. Esos suspiros narrativos. Me parece que es la mejor manera de terminar estos apuntes: un breve relámpago para una tormenta larga y novelesca. El micro-relato se titula "Olvido" o "Amnesia" y dice así:

En un lugar de La Mancha de cuyo nombre no puedo acordarme.

\section{El final}

$\mathrm{Y}$ eso es todo. O no. Porque imposible olvidarlo. En alguna otra parte - tan cerca y tan lejos - Juanjo alcanza a su Dulcinea, los luchadores enmascarados ensayan nuevas tomas y golpes de nombres absurdos, un Nabokov ectoplasmático continúa despotricando contra la prosa cervantina tan poco preocupada por las mariposas del estilo, Pierre Menard alcanza la última línea, y ciertos rincones de La Mancha continúan exactamente como estaban entonces.

Escribo esto a finales de septiembre, a pocas semanas del Año Quijote. Entonces, dentro de muy poco, el mundo no será Tlön. El mundo será un lugar inolvidable, una Mancha que todo lo cubrirá y que no podrá ser borrada.

Escribo estas últimas líneas a las tres de la mañana.

Hora de dormir.

Lo dijo Cervantes, no lo digo yo. Dijo Cervantes: "Mientras dormimos somos todos iguales".

A lo que yo sí agrego: "Y mientras leemos el Quijote, todos somos diferentes". Por más que - hogar, dulce, hogar y hospital, silencio, hospital - compartamos la misma enfermedad.

Y está bien que así sea.

Eso.

Vale. 